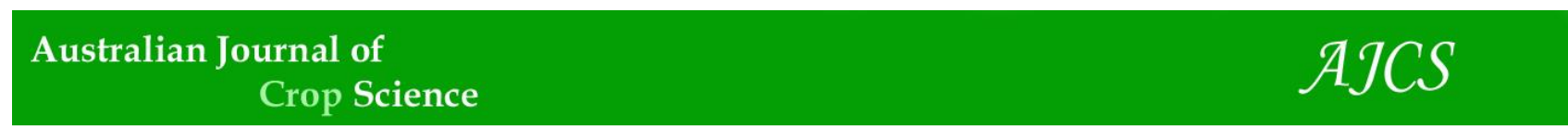

AJCS 12(07):1099-1107 (2018)

ISSN:1835-2707

doi: 10.21475/ajcs.18.12.07.PNE1024

\title{
Fungicides with physiological effects on the formation of grafted tomato seedlings
}

\author{
Amanda Cristina Esteves Amaro ${ }^{1}$, Daniel Baron ${ }^{2}$, Anamaria Ribeiro Pereira Ramos ${ }^{1}$, João Domingos \\ Rodrigues $^{3}$, Elizabeth Orika Ono ${ }^{3}$
}

${ }^{1}$ Faculdade de Ciências Agronômicas (FCA), Universidade Estadual Paulista “Júlio de Mesquita Filho" (UNESP), Botucatu Campus, Horticulture Department. CP-237, 18603-970, Botucatu-SP, Brazil

${ }^{2}$ Centro de Ciências da Natureza (CCN), Universidade Federal de São Carlos (UFSCar), Lagoa do Sino Campus, Plant Physiology and Biochemistry Laboratory. CP-094, 18290-000, Buri-SP, Brazil

${ }^{3}$ Instituto de Biociências (IB), Universidade Estadual Paulista “Júlio de Mesquita Filho" (UNESP), Botucatu Campus, Botany Department, CP-510, 18618-970, Botucatu-SP, Brazil

Corresponding author: amandaceamaro@gmail.com

\begin{abstract}
In tomato, grafting is being used as a preventive measurement of diseases control. During the grafting process, plants tend to overproduce reactive oxygen species in response to injury, controlling oxidative stress. It may be an important factor in achieving success in grafting. The present work aimed to evaluate if the before and after grafting application of pyraclostrobin and boscalid improves the activity of antioxidant enzymes and photosynthetic pigments, resulting in growth improvement of grafted tomato plants during graft union formation. The experimental design was in randomized blocks, with 7 treatments such as: control; pyraclostrobin $0.15 \mathrm{~g} \mathrm{~L}^{-1}$; boscalid $0.15 \mathrm{~g} \mathrm{~L}^{-1}$; pyraclostrobin $0.15 \mathrm{~g} \mathrm{~L}^{-1}+$ boscalid $0.15 \mathrm{~g} \mathrm{~L}^{-1}$; pyraclostrobin $0.25 \mathrm{~g} \mathrm{~L}^{-1}$; boscalid $0.25 \mathrm{~g} \mathrm{~L}^{-1}$; pyraclostrobin $0.25 \mathrm{~g} \mathrm{~L}^{-1}$ +boscalid $0.25 \mathrm{~g} \mathrm{~L}^{-1}$ in 6 replicates. These treatments were applied to the substrate, at sowing of the scion and rootstock and through foliar application 20 days after sowing and 4 days after grafting (DAG). The 'Pizzadoro' tomato plants were grafted onto 'Guardian', 30 days after sowing, using the splice grafting method. The antioxidant enzymes activities were evaluated at the hypocotyl region, and lipid peroxidation and photosynthetic pigments at leaves at 2, 8 and 14 DAG. Plant growth was evaluated at 2 and 14 DAG. Treatment with fungicides improved the physiological performance of the seedlings, increasing the relative growth rate. The results suggest that the preventive application of pyraclostrobin and boscalid is responsible for inducing the efficiency of the antioxidative system and the concentration of photosynthetic pigments in grafted tomato plants, contributing to the reestablishment of these plants.
\end{abstract}

Keywords: antioxidant enzymes, carboxamide, grafting, Solanum lycopersicum, strobilurin.

Introduction

Until recently, disease control was the main objective of the use of fungicides in agriculture. However, the physiological benefits of strobilurins have brought a new concept for the use of these products. Due to the plant's great ability to absorb them, these fungicides have positive physiological effects on the yield of the crops, modulating changes in plant metabolism and growth (Blandino et al., 2012; DiazEspejo et al., 2012). Carboxamides have also been included in this group of fungicides with positive physiological effects, but because they have been introduced for less time on the market, the information and experimental results with the molecules of this chemical fungicide group is scarce (Blandino et al., 2012; Jadoski et al., 2015).

The physiological effect of strobilurins is due to the increase of liquid photosynthesis and temporary reduction of plant respiration (Blandino et al., 2012; Jadoski et al., 2015). There is also an improvement in the hormonal balance of the vegetable, with an increase in the synthesis of abscisic acid (ABA) (Diaz-Espejo et al., 2012) and the reduction of ethylene synthesis (Ypema and Gold, 1999). In addition to reducing chlorophyll degradation, due to lower ethylene levels, strobilurins also increase cytokinin synthesis, which delays the degradation of chlorophyll and, consequently, produces the "green effect" in plants. The best photosynthetic performance and the reduction of chlorophyll degradation, combined with a better use of nitrogen, caused by the increase of the activity of the enzyme nitrate reductase (Lima et al., 2012) resulting in higher growth and productivity of the cultures, in which strobilurins are applied (Sarwat et al., 2013).

The application of strobilurins also results in a greater growth. Young banana plants treated with strobilurin presented higher height and dry mass of shoot and leaf area, when compared to untreated plants (Lima et al., 2012). Bean plants treated with pyraclostrobin also showed higher absolute growth rate and higher leaf area (Kozlowski et al., 2009), as well as soybean which presented increase of dry mass (Joshi et al., 2014) and wheat plants after epoxiconazole plus trifloxystrobin (Ishikawa et al., 2012). 
Thus, the senescence process is also delayed due to the increase of the antioxidant enzymes activity, such as superoxide dismutase (SOD), catalase (CAT) and peroxidase (POD), slowing down the superoxide $\left(\mathrm{O}_{2}{ }^{\circ-}\right)$ production $(\mathrm{Wu}$ and von Tiedemann, 2001; Jadoski et al., 2015). Later, the same authors verified that the preventive application of azoxystrobin in barley reduces the damages caused by ozone, since it increases the activity of the antioxidative system [SOD, CAT, POD, ascorbate-peroxidase (APX) and glutathione reductase $(G R)]$, reducing the levels of superoxide $\left(\mathrm{O}_{2}{ }^{\mathrm{O}}\right)$, as a protector against this stress $(\mathrm{Wu}$ and von Tiedemann, 2002). The application of azoxystrobin in wheat plants delayed the formation of lipid peroxidation, electrolyte leakage and degradation of proteins and chlorophylls in leaflets, indicating a delay in the senescence process. In addition, these plants showed an increased activity of SOD, CAT and POD enzymes, showing a protective effect of the antioxidative system (Zhang et al., 2010).

Most of the results present in the literature were obtained from evaluation of large crops, such as soybean (Joshi et al., 2014), corn (Blandino et al., 2012), wheat (Ishikawa et al., 2012; Ypema and Gold, 1999) and bean (Jadoski et al., 2015; Kozlowski et al., 2009). There are a few reports in vegetables, despite also being used preventively in these plants, especially in the species of the Solanaceae and Cucurbitaceae families. Studies on physiological changes in this subject have many controversies and few data on these effects in disease-free plants are available.

In vegetables, grafting is used as a preventive measure, mainly in crops in protected environment with successive crops, aiming at the control of diseases to avoid the contact of the plant with the pathogen (Martínez-Ballesta et al., 2010). Grafting confers numerous advantages, such as an increased nutrient absorption (Martínez-Ballesta et al., 2010), vigor of the plant and resistance to climatic adversities, such as low temperatures (Schwarz et al., 2010), drought tolerance (Schwarz et al., 2010) and soil salinity (Colla et al., 2012), besides controlling physiological disorders (Martínez-Ballesta et al., 2010) and improving the external appearance of the fruits (Rouphael et al., 2010). In addition, it increases tolerance to heavy metals and organic pollutants (Savvas et al., 2010). Grafting is a technique of vegetative propagation, involving the union of parts of two plants through the regeneration of tissues (San Bautista et al., 2011). After cellulose, lignin is the most abundant known natural organic product (Rastogi and Dwivedi, 2008) and it is mainly synthesized in the cells to become part of the vascular transport system. Therefore, it is very important during the cicatrization of grafting (Fernández-García et al., 2004).

In the formation of lignin the peroxidases act in polymerization inside the cell wall, forming a complex coordinated with hydrogen peroxide. This provides the $\mathrm{H}_{2} \mathrm{O}_{2}$ necessary for the oxidation of the cinnamic acid and converts the ferulic acid to diferulic, which acts in the bridge of hemicellulose. This bridge binds the cinnamic acid to the proteins and the carbohydrates of the cellular wall, favoring the consolidation (Vanholme et al., 2008). Fernández-García et al. (2004) verified that the grafted tomato plants have high peroxidase activity during the development of the seedlings. The peroxidase activity was decreased when they measured $2 \mathrm{~mm}$ above or below the graft region, similar to the ungrafted plants, suggesting that a greater activity is concentrated in the region of healing.

The present work aimed to evaluate application of pyraclostrobin and boscalid, before and after grafting to improve the activity of antioxidant enzymes and photosynthetic pigments, resulting in growth improvement of grafted tomato (Solanum lycopersicum L.) plants during graft union formation.

\section{Results}

Lipid peroxidation and activities of the enzymes superoxide dismutase, peroxidase and catalase

The activity of antioxidant enzymes, superoxide dismutase (SOD) and catalase (CAT) were evaluated in the grafting region at 2, 8 and 14 days after grafting (DAG). The lipid peroxidation was evaluated in the leaves at the same time to quantify the stress of these plants.

At 2 DAG, the plants did not start the post-grafting recovery process, which is evidenced by the high lipid peroxidation, showing no difference between treatments with fungicides (Fig 1A). In order to combat the reactive oxygen species (ROS), it is necessary to increase the activity of the antioxidative system. The control and plants treated with PIR $0.15 \mathrm{~g} \mathrm{~L}^{-1}$; PIR $0.15 \mathrm{~g} \mathrm{~L}^{-1}+$ BOS $0.15 \mathrm{~g} \mathrm{~L}^{-1}$; PIR $0.25 \mathrm{~g} \mathrm{~L}^{-}$ ${ }^{1}$; and BOS $0.25 \mathrm{~g} \mathrm{~L}^{-1}$ presented the highest activity of SOD (Fig 1B) and CAT (Fig 2A).

It is also observed that SOD activity was higher in the control plants compared to the fungicide treated plants, except for those treated with PIR $0.15 \mathrm{~g} \mathrm{~L}^{-1}+$ BOS $0.15 \mathrm{~g} \mathrm{~L}^{-1}$ ( Fig 1B). The highest activity of CAT at 2 DAG was also observed in the control plants. However, unlike the SOD, the plants of the treatments with pyraclostrobin at both doses showed high CAT activity (Fig 2A).

At 8 DAG, plants treated with boscalid at both doses showed high lipid peroxidation, but only those treated with BOS $0.15 \mathrm{~g} \mathrm{~L}^{-1}$ showed higher CAT activity. However, the plants treated with PIR $0.15 \mathrm{~g} \mathrm{~L}^{-1}+$ BOS $0.15 \mathrm{~g} \mathrm{~L}^{-1}$ presented the lowest lipid peroxidation, which corroborates the lower CAT activity presented by this treatment (Fig 2A).

At $14 \mathrm{DAG}$, the plants treated with the fungicide mixtures at both doses presented higher SOD activity than at 8 DAG. However, at 14 DAG plants treated with PIR $0.25 \mathrm{~g} \mathrm{~L}^{-1}+\mathrm{BOS}$ $0.25 \mathrm{~g} \mathrm{~L}^{-1}$ also showed the highest SOD activity, compared to the treatments, except for plants treated with PIR $0.15 \mathrm{~g} \mathrm{~L}^{-1}$ + BOS $0.15 \mathrm{~g} \mathrm{~L}^{-1}$ (Fig 1B). These results justify the lower values of lipid peroxidation presented by these treatments (Fig 1A). At 14 DAG, the highest activity of CAT was found in BOS $0.25 \mathrm{~g} \mathrm{~L}^{-1}$ treatment but without differing from the treatments PIR $0.25 \mathrm{~g} \mathrm{~L}^{-1}+$ BOS $0.25 \mathrm{~g} \mathrm{~L}^{-1}$ (Fig 2A).

The POD activity was increased during the development of the grafted seedlings. The control and treated plants with $0.15 \mathrm{~g} \mathrm{~L}^{-1}$ PIR presented the highest POD activity at 8 DAG (Fig $2 \mathrm{~B}$ ), a period in which the vascular connections were reestablished. Plants treated with BOS $0.15 \mathrm{~g} \mathrm{~L}^{-1}$; PIR $0.15 \mathrm{~g} \mathrm{~L}^{-1}$ + BOS 0.15g L $\mathrm{L}^{-1}$; PIR 0.25g L $\mathrm{L}^{-1}$; and PIR 0.25g L $\mathrm{L}^{-1}+\mathrm{BOS} 0.25 \mathrm{~g} \mathrm{~L}^{-}$ ${ }^{1}$ also revealed higher POD activity over the same period, they showed a higher activity at 14 DAG (Fig 2B). It is also observed that, at 2 and 14 DAG, plants treated with PIR $0.25 \mathrm{~g} \mathrm{~L}^{-1}$ and BOS $0.25 \mathrm{~g} \mathrm{~L}^{-1}$ presented higher POD activity than the other treatments (Fig 2B). 


\section{Growth of grafted plants}

The growth of the grafted seedlings treated with different fungicides was evaluated at 2 and 14 DAG. At 2 DAG, plants treated with PIR $0.15 \mathrm{~g} \mathrm{~L}^{-1}+\mathrm{BOS} 0.15 \mathrm{~g} \mathrm{~L}^{-1}$; PIR $0.25 \mathrm{~g} \mathrm{~L}^{-1}$; and PIR 0.25g L $\mathrm{L}^{-1}+\mathrm{BOS} 0.25 \mathrm{~g} \mathrm{~L}^{-1}$ presented lower height (Fig 3A) and total dry mass (Fig 4B), than the other treatments. In addition, these same treatments had a higher relative growth rate (Fig 5 ), which resulted in no difference between treatments for height (Fig $3 \mathrm{~A}$ ) and total dry mass (Fig 4B) at 14 DAG.

It is observed that, at 2 DAG, all the plants treated with fungicides showed a higher increase of the leaf area compared to the control (Fig 3B). All treatments showed an increased leaf area at 14 DAG, but without statistical differences between them. At $2 \mathrm{DAG}$, the treatments did not differ in leaf dry mass (Fig 4A). It is worth mentioning that the control plants showed an increase in leaf dry mass, at 14 DAG.

\section{Photosynthetic pigments}

The photosynthetic pigments of the grafted seedlings treated with different fungicides were evaluated at 2 and 14 DAG. At 2 DAG, chlorophyll $a$ concentration was higher in plants treated with PIR $0.15 \mathrm{~g} \mathrm{~L}^{-1}$ and PIR $0.25 \mathrm{~g} \mathrm{~L}^{-1}+\mathrm{BOS}$ $0.25 \mathrm{~g} \mathrm{~L}^{-1}$, in relation to PIR $0.25 \mathrm{~g} \mathrm{~L}^{-1}$; BOS $0.15 \mathrm{~g} \mathrm{~L}^{-1}$; and PIR $0.15 \mathrm{~g} \mathrm{~L}^{-1}+$ BOS $0.15 \mathrm{~g} \mathrm{~L}^{-1}$ (Fig 6A). However, the concentration of chlorophyll $b$ in plants treated with $0.15 \mathrm{~g} \mathrm{~L}^{-}$ ${ }^{1}$ PIR was only higher than those treated with BOS $0.15 \mathrm{~g} \mathrm{~L}^{-1}$ and PIR 0.15g L $\mathrm{g}^{-1}+$ BOS $0.15 \mathrm{~g} \mathrm{~L}^{-1}$ (Fig 6B). At 14 DAG, concentrations of chlorophyll $a$ and $b$ of plants treated with PIR 0.15 $\mathrm{g} \mathrm{L}^{-1}$ and BOS $0.15 \mathrm{~g} \mathrm{~L}^{-1}$ was decreased compared to the previous evaluation. The lowest concentration of these pigments occurred using BOS $0,15 \mathrm{~g} \mathrm{~L}^{-1}$.

Regarding the carotenoid concentration, plants treated with PIR $0.25 \mathrm{~g} \mathrm{~L}^{-1}+\mathrm{BOS} 0.25 \mathrm{~g} \mathrm{~L}^{-1}$ presented higher values than those treated with BOS $0.15 \mathrm{~g} \mathrm{~L}^{-1}$ in both evaluations (Fig 6C).

\section{Discussion}

Apparently, the physiological effects of these fungicides are mostly noticeable when the plant has passed or undergone some type of stress, causing them to act as protectors for the stresses. During the grafting process, plants tend to overproduce ROS. The production of ROS is one of the primary events in response to injury and controlling oxidative stress, which may be an important factor in achieving success in grafting (Irisarri et al., 2015; Liu et al., 2014).

In the present study, high lipid peroxidation was observed, due to the recent grafting injury at $2 \mathrm{DAG}$, when plants have not initiated the post-grafting restoration process yet. This was accompanied by an increase in SOD and CAT activity in the plants treated with PIR $0.15 \mathrm{~g} \mathrm{~L}^{-1}$; PIR $0.15 \mathrm{~g} \mathrm{~L}^{-1}+\mathrm{BOS}$ $0.15 \mathrm{~g} \mathrm{~L}^{-1}$; PIR $0.25 \mathrm{~g} \mathrm{~L}^{-1}$; and BOS $0.25 \mathrm{~g} \mathrm{~L}^{-1}$; however, higher fungicide mixture (PIR $0.15 \mathrm{~g} \mathrm{~L}^{-1}+\mathrm{BOS} 0.15 \mathrm{~g} \mathrm{~L}^{-1}$ ) reflected lower lipid peroxidation at 8 DAG. The fungicide mixture at both dosages also increased the activity of antioxidant enzymes at 14 DAG.

The application of strobilurins increased the activity of antioxidant enzymes (SOD, CAT and POD), controlling the action of superoxide $\left(\mathrm{O}^{2-}\right)$, reducing oxidative stress, and consequently, delaying lipid peroxidation and electrolyte extravasation, acting as protectors against these stresses (Zhang et al., 2010).

In grafted tomato plants, the differentiation of callus cells to form new vascular connections occurs between 4 and 8 DAG, when the sap flow is restored and the vascular connections are formed at 15 DAG (Fernández-García et al., 2004). It is worth mentioning that, 14 DAG is the moment that these seedlings are ready to be planted in the field and the acclimatization of the seedlings is critical for their survival (Lee et al., 2010), because in the field they will find new situations of environmental stress. One of the biggest challenges of agriculture is to manage this stress caused by ROS (Tartoura and Youssef, 2011), increasing the activity of antioxidant enzymes by the preventive application of fungicides. This may help the acclimatization of these grafted plants when transplanted to the field.

The lignin must be synthesized to become part of the vascular transport system and; therefore, it is very important during the cicatrization of the graft. For that, the POD acts in polymerization inside the cell wall (Vanholme et al., 2008). For this reason, during the development of grafted plants, the activity of this enzyme is increased in the region of grafting and this is essential during this process (FernándezGarcía et al., 2004). Thus, the increase of POD activity after the application of pyraclostrobin during this process may help in the formation of new vascular connections and; thus, in the restoration of the grafted seedlings. In the present study, it is evidenced that the application of PIR $0.25 \mathrm{~g} \mathrm{~L}^{-1}$ increased POD activity at 2 DAG and PIR $0.15 \mathrm{~g} \mathrm{~L}^{-1}$ at 8 DAG, period in which vascular connections are established. Plants treated with BOS $0.15 \mathrm{~g} \mathrm{~L}^{-1}$; PIR $0.15 \mathrm{~g} \mathrm{~L}^{-1}+\mathrm{BOS} 0.15 \mathrm{~g} \mathrm{~L}^{-1}$; PIR $0.25 \mathrm{~g} \mathrm{~L}^{-1}$; And PIR $0.25 \mathrm{~g} \mathrm{~L}^{-1}+$ BOS $0.25 \mathrm{~g} \mathrm{~L}^{-1}$ also revealed increase in POD activity in the same period. They showed a higher activity at 14 DAG.

The higher activity of the antioxidative system, and consequently, lower stress in the plants treated with the fungicides PIR $0.15 \mathrm{~g} \mathrm{~L}^{-1}+$ BOS $0.15 \mathrm{~g} \mathrm{~L}^{-1}$; PIR $0.25 \mathrm{~g} \mathrm{~L}^{-1}$; and PIR $0.25 \mathrm{~g} \mathrm{~L}^{-1}+$ BOS $0.25 \mathrm{~g} \mathrm{~L}^{-1}$ resulted in a higher relative growth rate of the seedlings, which is crucial in the vegetative development. Higher absolute growth rate and higher rate of leaf area were also observed in common bean plants treated with pyraclostrobin (Kozlowski et al., 2009).

It can be observed that all plants treated with fungicides showed a higher increase of leaf area at 2 DAGs compared to the control. However, no differences were observed in height, total dry mass and leaf area between treatments at 14 DAG. Factor et al. (2011) observed contrary results in tomato seedlings treated with pyraclostrobin solution in the substrate, in which after sowing they observed greater shoot growth, number of leaves and root system.

Banana saplings treated with strobilurins also had a greater height and diameter of the pseudostem, shoot dry weight and leaf area compared with untreated plants (Lima et al., 2012). Soybean plants (Joshi et al., 2014) and wheat (Ishikawa et al., 2012) presented increase in dry mass after application of epoxiconazole + trifloxystrobin. Perhaps the application of strobilurins results in higher growth of ungrafted seedlings, but when grafted this benefit was not observed in the present study.

The higher growth of the seedlings was expected due to increase of the liquid photosynthesis and better hormonal 

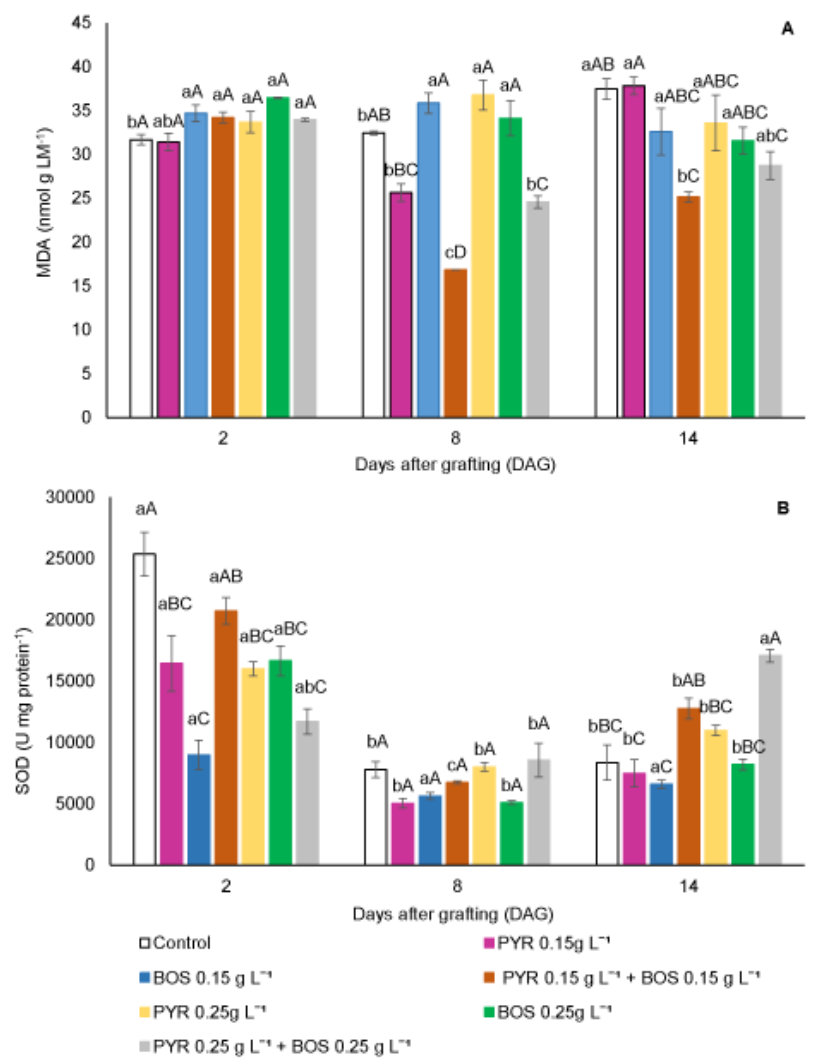

Fig 1. Lipid peroxidation (MDA) (A) in the leaves, and superoxide dismutase activity (SOD) (B) in the hypocotyl region of tomato plants (Solanum lycorpersicum L.) 'Pizzadoro' grafted onto 'Guardian', treated with fungicides (PIR - pyraclostrobin, BOS - boscalid) at 2, 8 and 14 days after grafting (DAG). Values followed by the same letter do not differ statistically according to the Tukey Test ( $p$ $\leq 0.05, n=6$ ). Capital letters for fungicides and lowercase letters for assessments.
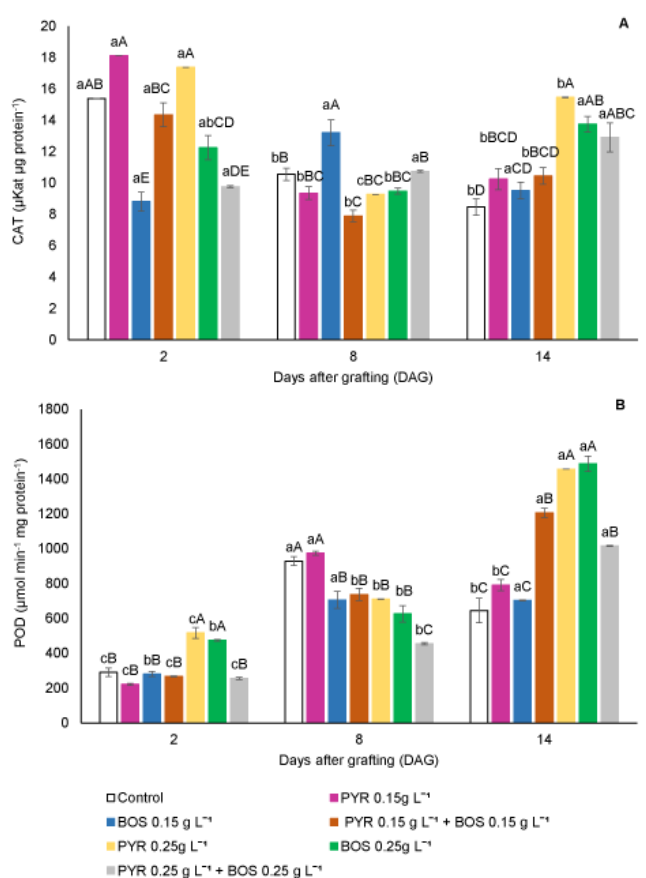

Fig 2. Catalase activity (CAT) (A) and peroxidase activity (POD) (B) in the hypocotyl region of tomato plants (Solanum lycorpersicum L.) 'Pizzadoro' grafted onto 'Guardian', treated with fungicides (PIR - pyraclostrobin, BOS - boscalid) at 2, 8 and 14 days after grafting (DAG). Values followed by the same letter do not differ statistically according to the Tukey Test $(p \leq 0.05, n=6)$. Capital letters for fungicides and lowercase letters for assessments. 

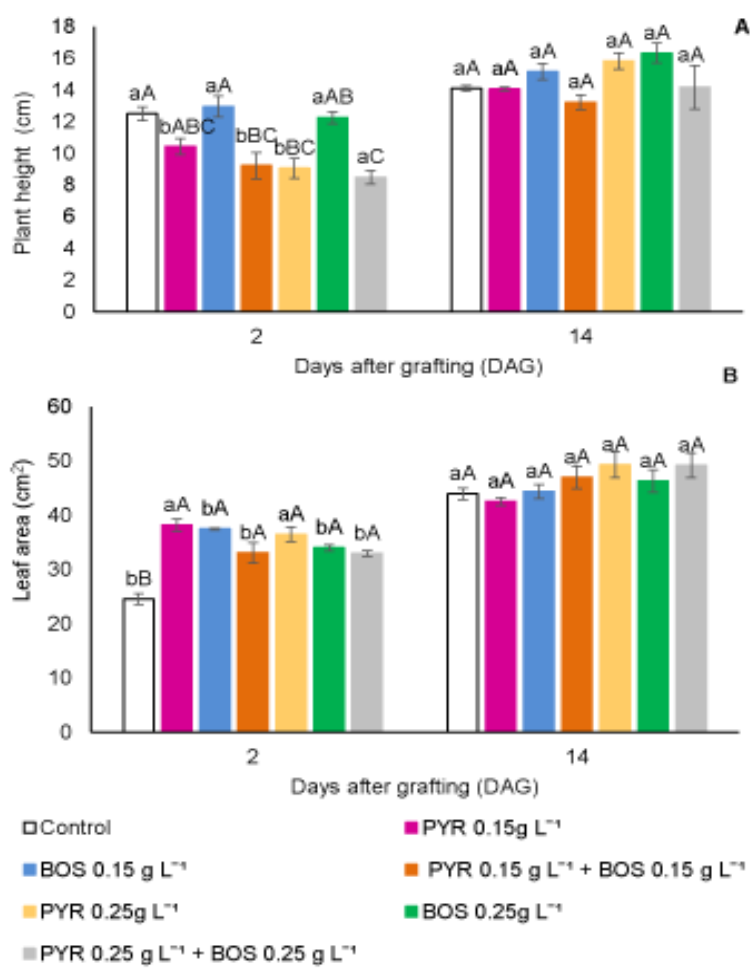

Fig 3. Plant height (A) and leaf area (B) of tomato plants (Solanum lycorpersicum L.) 'Pizzadoro' grafted onto 'Guardian', treated with fungicides (PIR - pyraclostrobin, BOS - boscalid) at 2 and 14 days after grafting (DAG). Values followed by the same letter do not differ statistically according to the Tukey Test $(p \leq 0.05, n=6)$. Capital letters for fungicides and lowercase letters for assessment.
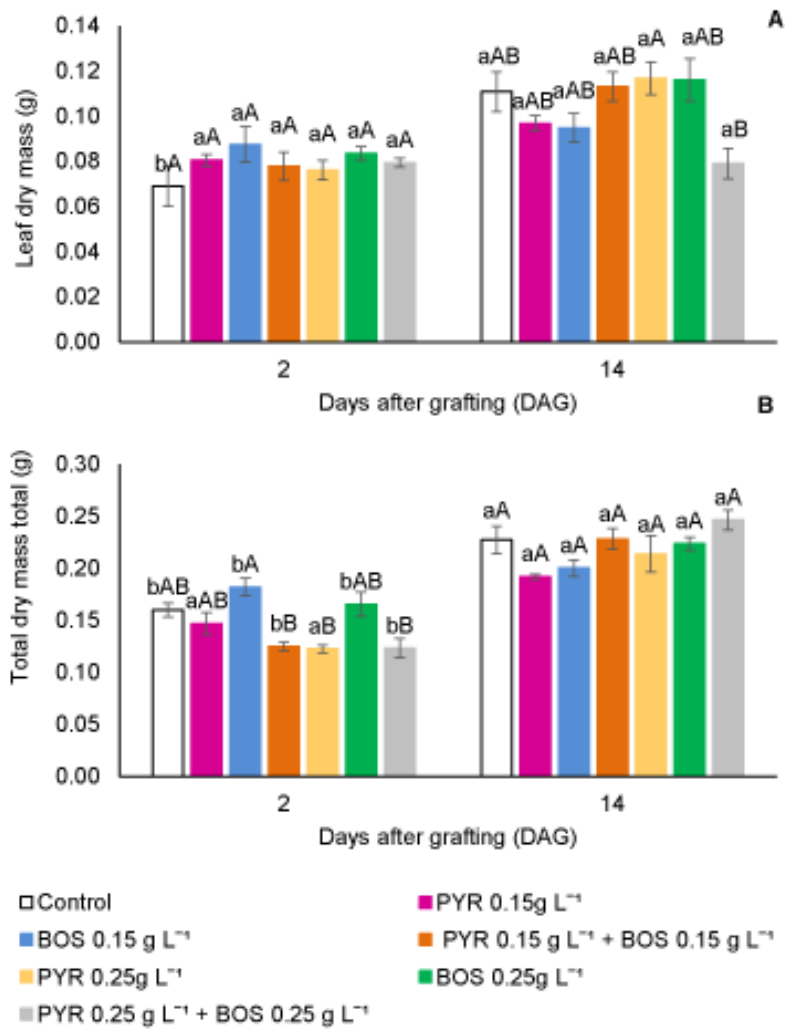

Fig 4. Leaf dry mass (A) and total dry mass (B) of tomato plants (Solanum lycorpersicum L.) 'Pizzadoro' grafted onto 'Guardian', treated with fungicides (PIR - pyraclostrobin, BOS - boscalid) at 2 and 14 days after grafting (DAG). Values followed by the same letter do not differ statistically according to the Tukey Test $(p \leq 0.05, n=6)$. Capital letters for fungicides and lowercase letters for assessments. 


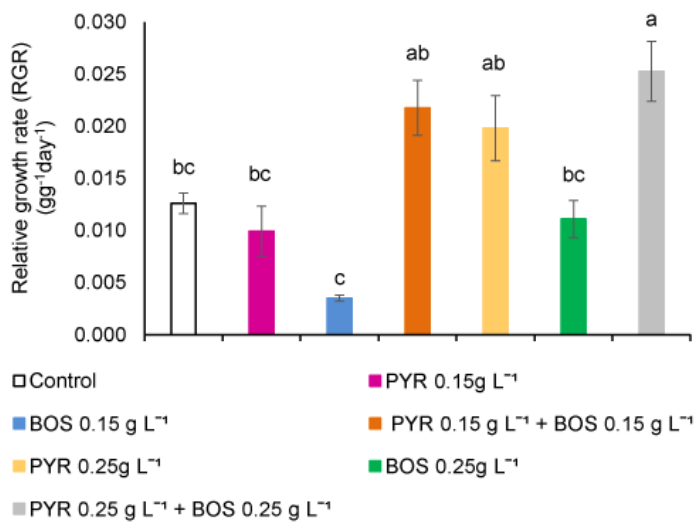

Fig 5. Relative growth rate (RGR) of tomato plants (Solanum lycorpersicum L.) 'Pizzadoro' grafted onto 'Guardian', treated with fungicides (PIR - pyraclostrobin, BOS - boscalid). Values followed by the same letter do not differ statistically according to the Tukey Test $(p \leq 0.05, n=6)$.
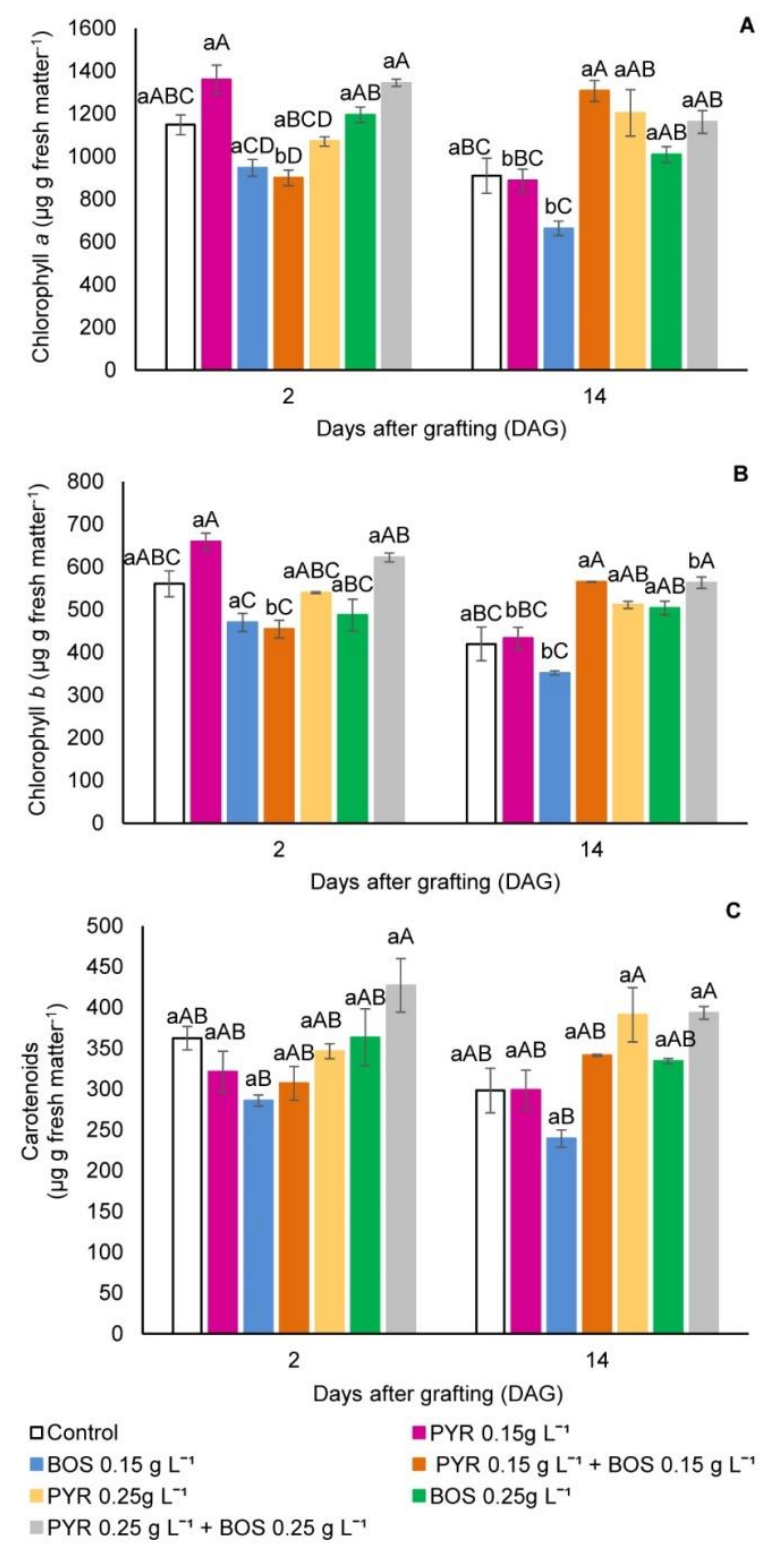

Fig 6. Concentration of chlorophyll $a(\mathrm{~A})$, chlorophyll $b(\mathrm{~B})$ and carotenoids (C) in the leaves of tomato plants (Solanum lycorpersicum L.) 'Pizzadoro' grafted onto 'Guardian', treated with fungicides (PIR - pyraclostrobin, BOS - boscalid) at 2 and 14 days after grafting (DAG). Values followed by the same letter do not differ statistically according to the Tukey Test $(p \leq 0.05, n=6)$. Capital letters for fungicides and lowercase letters for assessments. 
balance presented in plants treated with strobilurins. Strobilurins decrease ethylene synthesis under stress and senescence conditions by reducing the activity of the aminocyclopropane carboxylic acid synthase enzyme (ACCsynthase) inhibiting ethylene synthesis. Low ethylene concentrations decrease the degradation of cytokinins (Ypema and Gold, 1999), increasing their synthesis, delaying the degradation of chlorophyll, causing the so-called "green effect" on plants. The reduction of chlorophyll degradation, combined with better nitrogen utilization, slows down plant senescence and increases plant growth (Sarwat et al., 2013). The stress peak of the grafted tomato plants occurs at 2 DAG, as discussed previously, which possibly increase ethylene concentrations; thus, chlorophyll degradation. However, plants treated with PIR $0.15 \mathrm{~g} \mathrm{~L}^{-1}$ and PIR $0.25 \mathrm{~g} \mathrm{~L}^{-1}+$ BOS $0.25 \mathrm{~g} \mathrm{~L}^{-1}$ showed higher concentrations of chlorophyll $a$. Application of PIR $0.15 \mathrm{~g} \mathrm{~L}^{-1}$ presented higher concentration of chlorophyll $b$, indicating the efficiency of these fungicides delay chlorophyll degradation.

\section{Materials and Methods}

\section{Plant material and fungicide treatments}

Seeds of 'Pizzadoro' tomato (rootstock) and 'Guardião' tomato (scion) were sown in polystyrene trays with one seed per cell, with substrate recommended for the production of vegetables, covered with vermiculite. Soon after sowing, the substrates were saturated using water + fungicide solutions $\left(1^{\text {st }}\right.$ treatment application). The treatments with fungicides were: control (water); pyraclostrobin $0.15 \mathrm{~g} \mathrm{~L}^{-1}$; boscalid 0.15 $\mathrm{g} \mathrm{L}^{-1}$; pyraclostrobin $0.15 \mathrm{~g} \mathrm{~L}^{-1}+$ boscalid $0.15 \mathrm{~g} \mathrm{~L}^{-1}$; pyraclostrobin $0.25 \mathrm{~g} \mathrm{~L}^{-1}$; boscalid $0.25 \mathrm{~g} \mathrm{~L}^{-1}$; pyraclostrobin $0.25 \mathrm{~g} \mathrm{~L}^{-1}+$ boscalid $0.25 \mathrm{~g} \mathrm{~L}^{-1}$.

The boscalid source (carboxamide) was the product Cantus, containing $500 \mathrm{~g} \mathrm{~kg}^{-1}$ a.i. and for pyraclostrobin (strobilurin), the product Cabrio Top , containing $50 \mathrm{~g} \mathrm{~kg}^{-1}$ a.i. $+550 \mathrm{~g} \mathrm{~kg}^{-1}$ of methiram, both produced by BASF S.A.

After sowing and saturating the substrate with the fungicide solutions, the trays were placed in a germination chamber with a temperature of $20^{\circ} \mathrm{C}$ and a relative humidity of $90 \%$. After this period, the trays were taken to the greenhouse with a temperature of $25 \pm 1{ }^{\circ} \mathrm{C}$ and photoperiod of 12 hours.

When the 'Pizzadoro' tomato plants presented 3 to 4 leaves at 30 days after sowing, they were grafted using the splice grafting method (Lee et al., 2010). The graft and rootstock were secured by a silicone clamp, then the seedlings were placed in a humid chamber, formed by a 30 $\mathrm{cm}$ high plastic tunnel with $100 \%$ relative humidity. Exposure to light was prevented using cloth shade and aluminet screens covering the tunnel. After 5 days, the tunnel was ventilated daily in the morning until day 7 , when the plastic was removed.

Twenty days after sowing ( $2^{\text {nd }}$ application) and 4 days after grafting ( $3^{\text {rd }}$ application), new applications of the same treatments with fungicides were carried out via foliar spraying using a manual pressurized $\mathrm{CO}_{2}$ sprayer with $0.3 \mathrm{kgf}$ $\mathrm{cm}^{-2}$ with conical nozzles and using a plastic curtain between treatments to avoid drift.

\section{Activity of antioxidant enzymes}

At 2, 8 and 14 days after grafting (DAG) the hypocotyl region, where the grafting was performed, were collected and placed in plastic bags, wrapped in aluminum and immediately froze in liquid nitrogen to stop all metabolic reactions. The samples were stored in a $-80{ }^{\circ} \mathrm{C}$ freezer for further analysis.

For enzyme extracts, the samples $(300 \mathrm{mg}$ ) were pulverized in liquid nitrogen and homogenized in $4 \mathrm{~mL}$ of pre-cooled potassium phosphate buffer $(0.1 \mathrm{M}, \mathrm{pH} 6.8)$ and $200 \mathrm{mg}$ PVP. The homogenates were centrifuged at 10,000 $\mathrm{x}$ $\mathrm{g}$ for 10 minutes at $4{ }^{\circ} \mathrm{C}$, and the resulting supernatants were used for enzyme assays (Kar and Mishra, 1976). The soluble protein content was determined using casein as a standard (Bradford, 1976). The supernatant from the extraction was used to determine the activities of the enzymes superoxide dismutase (SOD, EC 1.15.1.1) (Beauchamp and Fridovich, 1971), peroxidase (POD, EC 1.11.1.7) (Teisseire and Guy, 2000) and catalase (CAT, EC 1.11.1.6) (Peixoto et al., 1999).

\section{Lipid peroxidation}

At 2, 8 and 14 days after grafting (DAG) leaf blades (200$400 \mathrm{mg}$ ) were collected and stored as described in the "Activity of antioxidant enzymes" section. The leaf blades were pulverized in liquid nitrogen and homogenized in $5 \mathrm{~mL}$ of solution containing $0.25 \%$ thiobarbituric acid (TBA) and $10 \%$ trichloroacetic acid (TCA). The extracted solution was incubated in a water bath at $90{ }^{\circ} \mathrm{C}$ for 60 minutes. After cooling, the solution was centrifuged at $10,000 \times \mathrm{g}$ for 15 minutes at room temperature $\left(25{ }^{\circ} \mathrm{C}\right)$. The supernatant collected from each sample was subjected to spectrophotometric absorbance readings at 560 and 600 $\mathrm{nm}$. For the calculations, the molar extinction coefficient of malondialdehyde (155 $\mathrm{mmol} \mathrm{L}^{-1} \mathrm{~cm}^{-1}$ ) was used (Rama Devi and Prasad, 1998).

\section{Photosynthetic pigments}

At 2,8 and 14 days after grafting (DAG) leaf blades (20$50 \mathrm{mg}$ ) were collected and placed in plastic bags, wrapped in aluminum and immediately frozen in liquid nitrogen to stop all metabolic reactions. The samples were stored in a $-80{ }^{\circ} \mathrm{C}$ freezer for further analysis. The leaf blades were pulverized in liquid nitrogen and homogenized in $3 \mathrm{~mL}$ of acetone/ Tris$\mathrm{HCl}$ buffer solution $(80: 20, \mathrm{v} / \mathrm{v}, \mathrm{pH} 7.8,0.2 \mathrm{M})$. The resulting suspension was transferred into falcon tubes $(15 \mathrm{~mL}$ capacity) and kept in a freezer at $-20{ }^{\circ} \mathrm{C}$ for one hour. The samples were then centrifuged at $10,000 \times \mathrm{g}$ for 5 minutes at $4{ }^{\circ} \mathrm{C}$. $1000 \mu \mathrm{mL}$ of the supernatant collected $+1000 \mu \mathrm{L}$ of acetone/Tris- $\mathrm{HCl}$ buffer solution were subjected to spectrophotometric absorbance readings at $663 \mathrm{~nm}, 647 \mathrm{~nm}$, $537 \mathrm{~nm}$ and $470 \mathrm{~nm}$. The concentration of chlorophyll $a$ and $b$ and carotenoids were calculated following the recommendations of Sims and Gamon (2002).

\section{Plant growth}

Plant growth was evaluated at 2 and 14 DAG, plant height, leaf area, leaf dry mass and total dry mass (composed of the sum of the dry masses of the stem, leaves and root) were evaluated. The leaf area was determined with the aid of leaf area meter LI-3000 (Li-Cor Inc., Lincoln NE, EUA). To obtain the total dry mass, the plant material was packed in paper bags and placed to dry in a forced circulation oven at $65{ }^{\circ} \mathrm{C}$ for 72 hours. From the growth data the relative growth rate 
(RGR) was calculated, which represents the variation of the dry mass as a function of the initial dry mass in a time interval $\left(\mathrm{gg}^{-1} \mathrm{day}^{-1}\right)$ (Radford, 1967).

\section{Statistical analyses}

The experimental design was in randomized blocks, with 7 treatments and 6 replicates. The Levene test was used to verify the homogeneity of the treatments. The results were subjected to analysis of variance (ANOVA), and the means were compared by the Tukey test $(p \leq 0.05)$ using the statistical tool SAS 9.2 (SAS Institute Inc., Cary, NC).

\section{Conclusion}

In the present study, high lipid peroxidation was observed at 2 DAG, when the plants have not started the post-grafting restoration process yet due to the recent grafting injury. This was accompanied by an increase in SOD and CAT activity in the plants treated with PIR $0.15 \mathrm{~g} \mathrm{~L}^{-1}$; PIR $0.15 \mathrm{~g} \mathrm{~L}^{-1}$ + BOS $0.15 \mathrm{~g} \mathrm{~L}^{-1}$; PIR $0.25 \mathrm{~g} \mathrm{~L}^{-1}$; and BOS $0.25 \mathrm{~g} \mathrm{~L}^{-1}$. However, higher fungicide mixture (PIR $0.15 \mathrm{~g} \mathrm{~L}^{-1}+$ BOS $0.15 \mathrm{~g} \mathrm{~L}^{-1}$ ), caused lower lipid peroxidation at 8 DAG. The fungicide mixture at both dosages also increased the activity of antioxidant enzymes at 14 DAG. Treatment with fungicides increased the relative growth rate of the seedlings, but no differences were found regarding height, leaf area, leaf dry mass and total dry mass. The results of the present study suggests that the preventive application of pyraclostrobin and boscalid is responsible for inducing the efficiency of the antioxidative system in grafted tomato plants, contributing to the reestablishment of these plants and possibly aiding them in acclimatization when transplanted to the field.

\section{Acknowledgments}

The authors thank the HIDROCERES company for the technical support in the conduction of this experiment.

\section{References}

Beauchamp C, Fridovich I (1971) Superoxide dismutase: improved assays and an assay applicable to acrylamide gels. Anal Biochem. 44:276-287.

Blandino M, Galeazzi M, Savoia W, Reyneri A (2012) Timing of azoxystrobin+propiconazole application on maize to control northern corn leaf blight and maximize grain yield. Field Crops Res. 139:20-29.

Bradford MM (1976) A rapid and sensitive method for the quantitation of microgram quantities of protein utilizing the principle of protein-dye binding. Anal Biochem. 72:248-254

Colla G, Rouphael Y, Rea E, Cardarelli M (2012) Grafting cucumber plants enhance tolerance to sodium chloride and sulfate salinization. Sci Hortic-Amsterdam. 135:177185.

Diaz-Espejo A, Cuevas MV, Ribas-Carbo M, Flexas J, Martorell S, Fernández JE (2012) The effect of strobilurins on leaf gas exchange, water use efficiency and $A B A$ content in grapevine under field conditions. J Plant Physiol. 169:379386.

Factor TL, Júnior SL, Purquerio LFV (2011) Secondary effects of fungicides in tomato seedlings production. Acta Hortic. 923:269-275.
Fernández-García N, Carvajal M, Olmos E (2004) Graft union formation in tomato plants: peroxidase and catalase involvement. Ann Bot-London. 93:53-60.

Irisarri P, Binczycki P, Errea P, Martens HJ, Pina A (2015) Oxidative stress associated with rootstock-scion interactions in pear/quince combinations during early stages of graft development. J Plant Physiol. 176:25-35.

Ishikawa S, Hare MC, Kettlewell, PS (2012) Effects of strobilurin fungicide programmes and fertilizer nitrogen rates on winter wheat: leaf area, dry matter yield and nitrogen yield. J Agr Sci. 150:427-441.

Jadoski CJ, Rodrigues JD, Soratto RP, dos Santos CM, Ribeiro E (2015) Ação fisiológica da piraclostrobina na assimilação de $\mathrm{CO}_{2}$ e enzimas antioxidantes em plantas de feijão condicionado em diferentes tensões de água no solo. IRRIGA. 20:319.

Joshi J, Sharma S, Guruprasad KN (2014) Foliar application of pyraclostrobin fungicide enhances the growth, rhizobialnodule formation and nitrogenase activity in soybean (var. JS-335). Pestic Biochem Phys. 114:61-66.

Kar M, Mishra D (1976) Catalase, peroxidase, and polyphenoloxidase activities during rice leaf senescence. Plant Physiol. 57:315-319.

Kozlowski LA, Simões DFM, de Souza CD, Trento M (2009) Efeito fisiológico de estrobilurina $F 500$ no crescimento e rendimento do feijoeiro. Rev Acad Ciênc Agrár Ambient. 7:41-54.

Lee J-M, Kubota C, Tsao SJ, Bie Z, Echevarria PH, Morra L, Oda M (2010) Current status of vegetable grafting: diffusion, grafting techniques, automation. Sci HorticAmsterdam. 127:93-105.

Lima JD, da Silva Moraes W, da Silva SHM-G (2012) Respostas fisiológicas em mudas de banananeira tratadas com estrobilurinas. Semina. 33:77-86.

Liu J, Li J, Su X, Xia Z (2014) Grafting improves drought tolerance by regulating antioxidant enzyme activities and stress-responsive gene expression in tobacco. Environ Exp Bot. 107:173-179.

Martínez-Ballesta MC, Alcaraz-López C, Muries B, MotaCadenas C, Carvajal M (2010) Physiological aspects of rootstock-scion interactions. Sci Hortic-Amsterdam. 127:112-118.

Peixoto PHP, Cambraia J, Sant'Anna R, Mosquim PR, Moreira, MA (1999) Aluminum effects on lipid peroxidation and on the activities of enzymes of oxidative metabolism in sorghum. Rev Bras Fisiol Veg. 11:137-143.

Radford PJ (1967) Growth Analysis Formulae - Their Use and Abuse1. Crop Sci. 7:171-175.

Rama Devi S, Prasad MNV (1998). Copper toxicity in Ceratophyllum demersum L. (Coontail), a free floating macrophyte: response of antioxidant enzymes and antioxidants. Plant Sci. 138:157-165.

Rastogi S, Dwivedi UN (2008) Manipulation of lignin in plants with special reference to O-methyltransferase. Plant Sci. 174:264-277.

Rouphael Y, Schwarz D, Krumbein A, Colla G (2010) Impact of grafting on product quality of fruit vegetables. Sci HorticAmsterdam. 127:172-179.

San Bautista A, Calatayud A, Nebauer SG, Pascual B, Maroto JV, López-Galarza S, (2011) Effects of simple and double grafting melon plants on mineral absorption, photosynthesis, biomass and yield. Sci Hortic-Amsterdam. 130:575-580. 
Sarwat M, Naqvi AR, Ahmad P, Ashraf M, Akram NA (2013) Phytohormones and microRNAs as sensors and regulators of leaf senescence: assigning macro roles to small molecules. Biotechnol Adv. 31:1153-1171.

Savvas D, Colla G, Rouphael Y, Schwarz D (2010) Amelioration of heavy metal and nutrient stress in fruit vegetables by grafting. Sci Hortic-Amsterdam. 127:156161.

Schwarz D, Rouphael Y, Colla G, Venema JH (2010) Grafting as a tool to improve tolerance of vegetables to abiotic stresses: thermal stress, water stress and organic pollutants. Sci Hortic-Amsterdam. 127:162-171.

Sims DA, Gamon JA (2002) Relationships between leaf pigment content and spectral reflectance across a wide range of species, leaf structures and developmental stages. Remote Sens Environ. 81:337-354.

Tartoura KAH, Youssef SA (2011) Stimulation of ROSscavenging systems in squash (Cucurbita pepo L.) plants by compost supplementation under normal and low temperature conditions. Sci Hortic-Amsterdam. 130:862868.
Teisseire H, Guy V (2000) Copper-induced changes in antioxidant enzymes activities in fronds of duckweed (Lemna minor). Plant Sci. 153:65-72.

Vanholme R, Morreel K, Ralph J, Boerjan W (2008) Lignin engineering. Curr Opin Plant Biol. 11:278-285.

Wu Y-X, von Tiedemann A (2001) Physiological effects of azoxystrobin and epoxiconazole on senescence and the oxidative status of wheat. Pestic Biochem Phys. 71(1):1-10.

Wu YX, von Tiedemann A (2002) Impact of fungicides on active oxygen species and antioxidant enzymes in spring barley (Hordeum vulgare L.) exposed to ozone. Environ Pollut. 116(1):37-47.

Ypema HL, Gold RE (1999) Kresoxim-methyl: modification of a naturally occurring compound to produce a new fungicide. Plant Dis. 83:4-19.

Zhang Y-J, Zhang X, Chen C-J, Zhou M-G, Wang H-C (2010) Effects of fungicides JS399-19, azoxystrobin, tebuconazloe, and carbendazim on the physiological and biochemical indices and grain yield of winter wheat. Pestic Biochem Phys. 98:151-157. 